\title{
The Situational Leadership Behavior, Organizational Culture and Human Resources Management Strategy in Increasing Productivity of Private Training Institutions
}

\author{
Fajar Pasaribu \\ Universitas Muhammadiyah Sumatera Utara, Indonesia \\ fajarpasaribu53@yahoo.co.id
}

\begin{abstract}
This study aims to analyze the relationship of situational leadership behavior with the organizational culture; the influence of situational leadership behavior and organizational culture on implementation of human resource management strategies; the effect of the implementation of the strategy of human resource management on productivity; the influence of situational leadership behavior, organizational culture and the implementation of human resource management strategies on the productivity of private vocational training institutes. While the type of research are descriptive and verificative using explanatory survey. The data collection is done using questionnaires, documentation and interviews, while the sampling technique used a Likert Summated Rating. The unit of analysis is the field of operation and delivery of training services and fields of administration. Data analysis is using path analysis. The results showed that the situational leadership behaviors significantly correlated with the organizational culture; the situational leadership behavior and organizational culture have a significant effect simultaneously and partially on the implementation of human resource management strategies in private vocational training institutions; the implementation of human resource management strategies have a significant effect on productivity improvement of private vocational training institutions; the situational leadership behavior, organizational culture and the implementation of human resource management strategy that have a significant effect simultaneously and partially to the increased productivity of private vocational training institutions in North Sumatera province.
\end{abstract}

Keywords: Situational Leadership Behavior, Organizational Culture and Human Resource Management Strategy, Productivity

\section{Introduction and Literature}

The job training services industry has a good prospect because the needs of people on the job training is not only for the workforce who are seeking a job and be self-employed but also for those who have got a job and have started in entrepreneurship. They want to have and increase the knowledge, skills and attitudes to be more productive in works. This prospect can be exploited by private vocational training institutions as an opportunity to provide better job training, in accordance with the expectations of society, especially for the workforce who need job training. The private vocational training institutions as institutions belong to the public services consist of service operation system and service delivery system. On the service operation system of training comprises a component in the overall of service business systems, whereby the input is processed and the product elements are created through a physical component and human resources (Lovelock, 2002, p. 60). The training institution as agency that has service operations training with high level of contact on customers which is an operating system services that require significant interaction between customers, personnel, training facilities and equipment services (Schroeder, 2000, p. 80). The training institutions have the characteristics namely, an intangible product that is a service activity between training and non-training personnel with participants, no ownership, along with the production of consumption. This is aligned with the opinion by Zeithaml \& Mary (2000, p.3), that the services have characteristics of activities such as intangible, not cause ownership, production and consumption occur simultaneously and production processes related or not related to the physical product.

In relation to the development of the service sector including job training services, it can not be separated from the demand to remain the quality of the operation and delivery of services. Various attempts have been made to improve the functioning of private vocational training institutions more efficient, so as to reach all levels of society. The central government has provided policy and operational guidelines for private vocational training institutions through an Act No. 13 of 2003. This Act establishes a private vocational training institutions as a training center belonging to the community that has the task of 
organizing vocational training to equip and improve the knowledge, skills and attitudes of work, both for the workforce and labor to improve competence in accordance with demand for labor market needs. The government policy related to the current employment situation where the growth of the labor force is higher than employment. In general, the labor force does not have the skills and attitudes that work according to industry demand, they still need the job training. Cushway (2002, p.114) states that training is a planned process to change knowledge, skills and attitudes of labor to increase productivity in all activities which is conducted for both new workers and for those need refreshment and enhancement of skills on any new equipment. This prospect can be exploited by private vocational training institutions as a business opportunity that has the mission of education and training. Perhaps, the operation and delivery of training services of private vocational training institutions can not be separated out of the demand to improve the productivity and quality of service. The success of vocational training institute which is visible from the training facility utilization rates is still low. This is thought to influence the behavior of the leadership of the implementation of the organizational culture and the implementation of human resource management strategies in private vocational training institutions. The limited research on leadership behavior, organizational culture and the implementation of human resource management strategy and productivity of private vocational training institutions, motivated the author to make a temporary observation.

The observation indicates that the productivity of private vocational training institutions in North Sumatera province is seen has low utilization of operating facilities and delivery of training services. Generally, it showed a private vocational training institutions is not ready to increase the productivity of service and to compete in the business world. This phenomenon is presumably because in addition to the lack of professionalism of the actors in the operation and delivery of training services, as well as the inappropriate leadership behavior, low level of implementation of the organization culture and human resource management strategy. The leadership behavior has not manifested in the behavior of the task, behavior of the relationship and not in accordance with the maturity level of subordinates. Giving instruction, motivation, direction and guidance as well as the mobilization of leadership training institute is not in accordance with the level of subordinates' maturity. In such situations, an effective and flexible leader is needed to adjust to the difference between the subordinate and the situation. The situational leadership theory states the leaders understand its behavior, the properties of subordinates and the situation before adopting a specific leadership behaviors (Gibson et al., 1997, p.20). The application of organization culture is not been effective which seen from labor's lack of awareness to cooperate in achieving the objectives, less creative, innovative and normative.

The private vocational training institutions have not been able to guarantee the quality of operation and service training to trainees. Some of the officer has the attitudes of unpleasant and often there is a delay in the operation and delivery of training services. The instructors often late arriving at the training operation, so that the trainees waited for long time. This makes the labors reluctant to attend training at the local private vocational training institutions, they would prefer to choose training programs in other areas inside and outside the country. The instructor competence is low both in mastery of skills and industry experience as well as training's methods. Most of the private vocational training institutions in North Sumatera province have not been doing training in accordance with the results of the analysis of training needs. This phenomenon is suspected due to the internal problems faced by the private vocational training institutions, namely low productivity and quality of service that is caused by the low level of implementation of human resource management strategy which is not supported by the behavior of the leadership and implementation of organizational culture. In general, private vocational training institutions have not been able to market its training programs. The reputation of private vocational training institutes is still below par, the quality of graduates is low, there are many graduates who are yet to get a job. The service performance is still below the expectations of participants. The trainees are not satisfied with the operation and service training institutions.

In the midst of the problems faced, the private vocational training institutions in North Sumatera province have an important role in the operation and delivery of training services to the community. It is expected to always strive in making the trainees become satisfied and loyal. This is consistent with the expectations of society to the private vocational training institutions in order to provide training services work better, always trying to improve service satisfaction oriented. In achieving its role, private vocational training institutions should be able to design training programs work appropriately and absorb a lot of trainees and graduates according to the needs of industry or market demand for labor. In achieving the goals, the private vocational training institutions internally seeks to manage its human 
resources. This is in accordance with the opinion of the scholars that the human resources not only as a factor of production to increase productivity of vocational training institutions but as intellectual capital which is an asset of the institution/company. If the job-training institutes led by leadership behavior with an appropriate organizational culture application and implementation of human resource management strategies, thus productivity and quality of job training services will increase as people's expectations. The strong leadership behavior is needed to overcome the changes in the external environment, such as business competition, government policies, technological advances and changes in socio-economic changes that affect the formula and implementation of human resource management strategies (Mello, 2002; p.107). The effective implementation of human resource management strategy requires leadership behavior and organizational culture to create a workforce that has the willingness and ability to perform activities that generate the performance, productivity and profitability of the company (Noe et al., 2000, p.53). In the implementation of the strategy, it required the commitment of human resources that are formed in the culture of the organization, so that they have a positive contribution. Human resources required to act more as a determinant of performance and driving performance to improve productivity and quality of operations and services as well as winning the competition in the business world. If the productivity and quality of operations and job training services increases, the trainees will be satisfied following the training program. If the expected trainee satisfaction is achieved, they will be loyal and tell to others.

The situational leadership behavior is a person's ability to influence the actions of human resources towards the achievement of organizational goals with a combination of task behavior, behavior and maturity subordinate relationship (Kreitner \& Kinichi, 2000, p.551). The leadership behaviors that can influence and direct the human resources have a diverse backgrounds of social, economic and different abilities. Moreover, it is expected to develop human resources profession, followed by administration of adequate compensation for performance and equitability. The income received by the leaders and their families, affect the productivity of labor training institutions. While the organizational culture is a common perception held by human resources as a member organization of the institution used as a system of shared meant to increase productivity and job satisfaction (Robbins 1998, p.308). The service providers in the service operation and delivery system which have high level of contact with customers require the support of the physical environment and personnel contacts to meet objectives that have been established by the institution/company (Schroeder, 2000, p.80). This is aligned with the opinion of Lovelock (2002, p.53) that the intensity of the interaction in the operation and delivery of services can take place with a high contact customers, labor, equipment, and other service facilities. The physical support such as facilities, equipment, location and personnel contact in operating activities and delivery of services are required for situational leadership and organizational culture in implementation of human resource management strategy. An effective implementation of strategies will generate employment who have the willingness (responsibility, confidence, motivation) and ability (knowledge, skills) as well as in influencing the attitudes of labor productivity, quality and profitability of the company (Noe et al., 2000, p.53; Mello, 2002, p.107; Kreitner \& Kinichi, 2003, p.67; Robbins, 2003, p.283).

The situational leadership behavior is based on the assumption that leadership behavior combines task behavior and the behavior of the maturity level of the relationship with the subordinates. The accuracy of situational leadership behavior with subordinate maturity level is required in achieving the company's productivity (Kreitner \& Kinichi, 2000, p.551). The situational leadership behavior is a manifestation of its ability to influence a group of people to achieve the goals of the organization that combines task behavior, behavioral relationships in accordance with the maturity level of subordinates. The situational leadership behaviors affect, change and direct the behavior of subordinates through cooperation and communication in order to work productively (Blanchard \& Hersey, 1993, p.192). The function of organizational culture in the operation and delivery of services are managed by the effective behavior of leadership through the implementation of human resource management strategies, in which can increase the productivity and satisfaction of labors and the institutions (Kreitner \& Kinichi, 2003, p. 86). Organizational culture serves as a mechanism to make, control, guide, and shape the attitudes of productive work which encourages the growth of the institution that have an influence on productivity and job satisfaction (Robbins, 1998).

The implementation of human resource management strategy with operational functions i.e. recruitment, selection, training, performance appraisal, compensation and labor relations increase the productivity of institutions and provide a positive contribution to the implementation of the strategy of the institution through applying the technology, capability of making a high quality product or service (Mello 2002, 
p.237). According to the study by Mello (2002, p.107), the implementation of human resource management strategies that can effectively improve the performance and productivity, labor satisfaction and customer satisfaction and increase the value of the securities to shareholders (enhanced shareholder value). Similarly a study by Noe et al. $(2000$, p.53) shows that the implementation of human resource management strategy has a decisive contribution to the improvement of performance, productivity, quality and profitability of the institution/company. Productivity is a measure of the quality and quantity of work performed by taking into account the cost of used labor resources. The productivity is a measure of performance that includes effectiveness and efficiency. While, the effectiveness means of achieving goals, and efficiency is the ratio between the effective output and input required to achieve it (Robbins, 2003, p.22). The productive workforce will reduce operating costs and ensure customer satisfaction, if supported by the leadership behavior, culture, systems and appropriate technology (Schroeder, 2000, p.84)

An increased productivity of training institutions influenced by the behavior of situational leadership, organizational culture application and execution of human resource management strategies. The increased of productivity, quality and profitability of the institution/company is an advantage in winning the competition or used as acompetitive advantage. The situational leadership behavior and organizational culture both have a positive relationship that can accommodate the capabilities of human resources in the implementation of human resource management strategy which has a positive effect on the productivity of the institution (Blancard \& Hersey, 1993; Kreitner \& Kinichi, 2000). Giving the clear, detailed and precise work's instructions or notices of the situational leadership behavior can affect subordinate to improve the productivity of the institution (Blanchard \& Hersey, 1993; Robbins, 1998; Kreitner \& Kinichi, 2000). The implementation of consultation from the situational leadership behavior can communicate in both directions between superiors and subordinates, and subordinates could participate in decision-making and increased productivity of institutions (Blanchard \& Hersey, 1993; Robbins, 1998; Kreitner \& Kinichi, 2000). The dimensions of participation in situational leadership behavior, a low degree of task behavior, behavior and the level of maturity of the subordinate relationship from moderate to high can increase the productivity of the institution (Blanchard \& Hersey, 1993)

The implementation of human resource management strategies are creating the human resources that could contribute positively to influence the productivity of the institution (Noe et al., 2000; Dessler, 2000; Mello, 2000). The right implementation of the recruitment and selection is to obtain high competence of workers to perform productive works (Mello, 2000; Noe et al., 2000). The implementation of effective training increase the competence of workers who have a positive influence on the productivity (Noe et al., 2000). The results of the implementation of the management and performance assessment can be used for the implementation of training programs and adequate compensation in an effort to improve the productivity of institutions (Mello, 2000; Noe et al., 2000; Dessler, 2000). The increasing needs of the people on the job training is demanded the leader of training institutions to deliver the most needed services and types of training programs with better methods, effective and efficient. Lovelock (2002) stated that the business is seen as a system consisting of service orperation, service delivery and service marketing system. These systems consist of parts that are not visible to consumers (technical core) and parts are seen by consumers (physical support and contact personnel).

The private individual vocational training institutions as a training provider has high-contact service, so that workers become part of the training operating system and delivery services to fulfill the objectives that have been set by the institution/company to the customers (Schroeder, 2000). Therefore, an increase in the willingness (responsibility, confidence, motivation) and ability (knowledge, skills) and attitudes of the participants managed by situational leadership behavior and organizational culture in the implementation of human resource management strategies would improve the productivity of the institution/company (Noe et al., 2000; Mello, 2002). The private vocational training institutions are expected to create excellent service quality in the training operating and service delivery system programs that can give satisfaction to the trainees. This can be done with the support facilities (physical support) owned by the training institutions and the delivery of employment services (contact personnel). Furthermore, according to Noe et al. (2000), the empowerment of environment (physical invironment) and an increase in workforce skills of training and non-training with the implementation of human resource management strategy led by the behavior of situational leadership and implementation of effective organizational culture will improve productivity, quality and profitability of the company. 
The situational leadership behavior with dimensions of instruction, consultation, participation and delegation affect the implementation of human resource management strategy (Kreitner \& Kinichi, 2000; Blanchard \& Hersey, 1993; Robbins, 1998) and the dimensions of organizational culture of constructive, passive defensive and aggressive-defensive affect the implementation of human resource management strategy (Kreitner \& Kinichi, 2003; Tiwana, 2001; Robbins, 2003), then the implementation of human resource management strategies with dimensions of recruitment, selection, training, performance appraisal, compensation and labor relations affect the productivity of private vocational training institutes (Mello, 2002; Becker et al., 2001). This study conceptually has identified the relevant independent variables, namely; the situational leadership behavior, organizational culture and implementation of human resource management strategy. As the dependent variable is the productivity of private vocational training institutes. According to Blanchard \& Hersey (1993); Kreitner \& Kinichi (2002), the dimension of situational leadership behaviors include the instruction or notify (telling), consultation or selling, participation and delegation. Theoretically situational leadership behavior and organizational culture both have a positive relationship, then the situational leadership behavior and organizational culture positively affect the implementation of human resource management strategies that have contributed to the productivity of the institution. The implementation of human resource management strategy supported by situational and cultural leadership behaviors can increase the productivity of institutions. There are four operating factors as the important input, namely; labor, capital, technology and physical facilities such as building and equipment.

Based on the conditions of private vocational training institutions as described above, the existing gap used as a central theme of the research problem, namely; the low use of the facilities by the public training institutions, so that the institution does not absorb trainees. The low use of the facilities caused by not observing the behavior of leadership and organizational culture that influence the implementation of human resource management strategies which result of low productivity of labor training institutions. The reason of the author in determining the central theme of the problem due to the situational leadership behavior and application of organizational culture to support the implementation of human resource management strategies that have contributed as a determinant in increased productivity and business success of the institution/company. The efforts to improve the productivity of training institutions need proper leadership behavior and organizational culture that is able to improve the ability of workers to increase productivity. Given the arguments, it is necessary to analyze the influence of situational leadership behavior, organizational culture and implementation human resource management strategies on productivity at the private training institute in North Sumatera province.

\section{Methodology}

The type of study is descriptive and verificative that aimed to get a picture and information about the behavior of the leadership, organizational culture, the implementation of human resource management strategies and productivity as well as, to test its effect on the increase in productivity of private vocational training institutes. Descriptive study aimed to obtain clearly about certain circumstances, while the verificative refers in determining the clarity of relationships and the influence of a variable or to test hypotheses by statistical test of path analysis that can answer all the formulated questions. There are two methods of survey are applied, namely descriptive and explanatory survey, while the unit of analysis is on the field of operation and delivery of training services (Assistant Director of Operations) and field of administration (Assistant Director of Administration and Finance).

Operationalization of Research Variables: A summary of operationalization of research variables is depicted in Table below:

Table 1: A Summary of Operationalization of Research Variables

\begin{tabular}{|c|c|c|c|}
\hline Variable & Dimension & Indicator & Scale \\
\hline $\begin{array}{l}\text { Situational } \\
\text { Behavior } \\
\left(\mathbf{X}_{\mathbf{1}}\right) \\
\text { Ability of superiors to } \\
\text { affect the subordinate } \\
\text { situation with a } \\
\text { combination of task } \\
\text { behavior, behavior and } \\
\text { maturity subordinate } \\
\text { relationship. }\end{array}$ & $\begin{array}{l}\text { Instruction or Notifying } \\
\text { High degree of task behavior, } \\
\text { low-level relationships and low } \\
\text { subordinate maturity level, less } \\
\text { capability and ready to } \\
\text { perform tasks to achieve } \\
\text { operational objectives. }\end{array}$ & $\begin{array}{l}\text { Ability of employers to set the institutions' goals } \\
\text { /productivity. } \\
\text { Ability the top managers to assign tasks and } \\
\text { responsibilities of the subordinate. } \\
\text { Accuracy of top managers in giving instructions } \\
\text { Ability of employers to give guidance } \\
\text { Ability to control the subordinate by the supervisor at a } \\
\text { low maturity level }\end{array}$ & Ordinal \\
\hline
\end{tabular}




\section{Consultation or Selling}

High degree of task behavior high degree of relationship level and subordinate low level of maturity to moderate, subordinates are not capable but ready to do the task.

\section{Participation}

Low degree of task behavior, high degree of relationships level and a moderate degree of maturity level to high of the subordinate, the subordinates are capable but not ready to perform tasks

\section{Delegation}

Low degree of task behavior, low of relationships level and a high degree of maturity level of subordinates, subordinates are capable and ready to perform the task.

\section{Constructive Organizational} Culture

Organizational

culture

motivate workers to interact and work together, unity, normative, giving awards to performance on the goal
Organizational Culture

$\left(\mathrm{X}_{2}\right)$

Form of owned assumption implicitly accepted by the working group, determine the feeling of working group, think and react.
Ability of superiors to assign tasks and responsibilities of the subordinate

Accuracy in facilitating the consultation

Include the suggestions of subordinates in decision making

Ability of employers to give guidance

Ability to motivate, harmonious labor relations

Ability of employers to control the work of subordinates.

Ability of superiors to cooperate with subordinates in determining the decision

Ability to motivate and ease of work

Ability superiors to communicate with subordinates

Ability of employers to avoid conflicts

Ability to provide support, attention to subordinate

Ability of employers to give the delegation of tasks and responsibilities

Ability of employers to authorize the achievement of objectives (productivity)

Consider the suggestions of subordinates in decision making.

Accuracy of top managers in giving proper and fair compensation

Ability of supervisor to control the subordinate at a high maturity level

Ability of leaders to encourage workers to be cooperate constructively

Ability of leaders to encourage innovative and creative workforce in preparing operating strategy.

Ability of leaders to encourage normative workforce to carry out the task on time

Ability of leaders to encourage workers to develop themselves

Ability of leader to give the reward to the supportive and constructive workforce.

Ability of leaders to give the reward to the honest and objective workfore.

. The ability of leaders to encourage workers to interact with co-workers.

Defensive passive of . Ability of leaders to encourage normative workforce.

Organizational Culture Ability of leaders to encourage the labors to felt agreed Organizational culture and consent the top managers.

encourages workers interact : Ability of leaders to encourage labor to avoid conflicts

with coworkers, normative, . Ability of leaders encourage labors of traditional prioritizing supervisor's conservative.

approval to achieve the goal. Ability of leaders to encourage labor of rapid environmental adaptation.

Ability of leaders to labors to obey instructions.

\section{Indicator}

. Ability of leaders to encourage workers to work quickly and safely.

. Ability of leaders to encourage labor to work normatively.

. Encourage the employment of opposition, highlighting

Organizational Culture, deficiencies for improvement

Aggresive- Defensive. Ability of leaders to encourage workers to work Culture push the labors to competitively.

serve fast, safe, normative. Ability of leaders to encourage labor to be critical of the opposition, power and shortcomings, appreciate the negative outlook

competitive. Ability of leaders to encourage labor to control subordinates

. Ability of leaders to encourage labor to appreciate the subordinate

. Ability of leaders to encourage workers to obtain victory in the competition

Ordinal

Ordinal

Ordina

Ordinal 
Implementation of Human Resource Management Strategy

$\left(\mathrm{X}_{3}\right)$

Implementation of an integrated master plan, coordinated, linking the role of managerial and operational role of $\mathrm{HR}$ management

\section{Pre-recruitment}

Recruitment planning process to obtain a description and job specification.

\section{Recruitment}

The process of obtaining a number of qualified job applicants as needed by institutions

\section{Internal recruitment}

The process of obtaining potential workforce with the placement back in training institutions

\section{External recruitment}

The process of obtaining workforce from an external source of training institutions

\section{Preselection}

Pre-selection of candidates to obtain workers with appropriate job qualification

\section{Selection}

The process of selecting qualified manpower as needed

\section{Written Selection}

Fulfillment of the basic requirements to ensure the ability of candidates for employment

\section{Pre-training}

The process of reviewing the factual data in accordance with the position of potential participants

Implementation of Training A process of fulfillment the labor qualification to fill the position in improving the productivity based on the pretraining

\section{Performance Assessment}

The process of comparing the performance with a standard and communicating the results to the workforce to determine rewards
Ability of leadership to acquire data for the description / specification work

Ability of leaders to prepare description / specification

Ordinal work for recruitment

Ability of the leadership to get qualified manpower as needed

Ordinal

Accuracy of leadership conveying on job related information within the institution.

Accuracy of leadership doing promotion or transfer of potential power

Ability leadership in putting back the potential labor force

Ability of leaders to recruit workers from the labor market.

Ability of leaders to recruit labor from the unions

Ability of leaders to recruit labor from the professional

(associations

Ability of leader to recruit labor through the Internet

Ability of leaders to provides job information

Ability of leaders to select prospective labor

Ability of leaders making the job requirements

Ordinal

Ability of leaders on the selection on a number of candidates for employment

Ordinal

Ability of the leaders to do the written test

Ability of leaders to investigate the background of applicants

Ability of leaders to test the competence of the Ordinal candidates

Ability of leaders to test the interests and responsibilities of candidates for employment

Ability of leaders to express the needs for training

Ability of leaders to analyze the organization

Ability of leaders to analyze the competency of the Ordinal candidates

Ability to analyze the exercise objective.

Ability of leaders to conduct the training program Ability of instructors to provide training materials based on the curriculum

Ability of instructors using appropriate training Ordinal methods

Ability of instructors use tools and training materials Ability of instructor to evaluate the training

Ability of leaders to assess the performance of subordinates

Ability to assess the performance by colleagues

Ability to assess the performance of superiors by multisources

Ordinal

Ability to assess the performance by the consultant

Ability of leaders to assess the performance of comparison method 


\begin{tabular}{|c|c|c|c|}
\hline & $\begin{array}{l}\text { Compensation } \\
\text { Everything that is received by } \\
\text { the workforce, both financial } \\
\text { and non-financial form as a } \\
\text { reward or remuneration for } \\
\text { his/her work }\end{array}$ & $\begin{array}{l}\text { Ability of leaders to use the labor compensation system. } \\
\text { Ability to use the suitability of ethical minimum wage } \\
\text { Ability to use the nonfinancial of wage salary policy } \\
\text { system } \\
\text { Ability of managers to consider the behavioral aspects }\end{array}$ & Ordinal \\
\hline & $\begin{array}{l}\text { Employment relationship } \\
\text { Fostering harmonious labor } \\
\text { relations and cooperation to } \\
\text { improve productivity }\end{array}$ & $\begin{array}{l}\text { Ability of leaders to implement the Act No. } 13 \text { of } 2003 \\
\text { Ability to use the Act No. } 2 \text { of } 2004 \\
\text { Ability to negotiate, solve problems and complaints of } \\
\text { workers }\end{array}$ & Ordinal \\
\hline $\begin{array}{l}\text { The institutions' } \\
\text { Productivity (Y) } \\
\text { Private Job Training in } \\
\text { the North Sumatera } \\
\text { province }\end{array}$ & $\begin{array}{l}\text { Comparison of the amount of } \\
\text { gross profit of training } \\
\text { operating results (output) by } \\
\text { the number of training costs } \\
\text { (input) within a certain period }\end{array}$ & $\begin{array}{l}\text { The level of the ratio of gross profit of the } \\
\text { operating results with the operating costs of } \\
\text { training multiplied by } 100 \%\end{array}$ & Ratio \\
\hline
\end{tabular}

Determination of Data Sources and Methods: The data used in the study consist of two sources, namely:

- Primary data, i.e. data obtained from the private vocational training institutions by means of interviews and questionnaires with respondents refer to the representative of the population. The questionnaire with Likert ordinal scale is structured. The data obtained by taking a sample of the population. The target population is the leader/assistant director that directly responsible to the director of private vocational training institutions in North Sumatera province.

- Secondary data, i.e. data obtained from the Department of Manpower and Transmigration and Central Bureau of Statistics (BPS) of North Sumatera province.

In accordance with the purpose of research, the minimum sample size is determined through iterative technique. The subjected samples to observation are the elements that are in the population, while the population is a collection of the sampling unit that includes one or more units of the elements (Sekaran, 2000,p.255). The sampling of this study based on a sample size of Yamane (in Djalaludin, 2000, p.82), which is done by determining the value of precision (d) of $5 \%$ as follows:

$$
n=\frac{N}{N d^{2}+1}
$$

Furthermore, for the allocation of private vocational training institutions based on each district/city of North Sumatera Province used the principle of proportional allocation, using the formula as follows:

$$
n_{i}=\frac{N i}{N} \times n
$$

Where:

$\mathrm{n}_{\mathrm{i}} \quad=$ size of sample to be taken from the center to $-\mathrm{i}$

$\mathrm{N}_{\mathrm{i}} \quad=$ size of the center to $-\mathrm{i}$

$\mathrm{N} \quad=$ population size

$\mathrm{n} \quad=$ total sample size allocated

$\mathrm{d} \quad=$ Precision desired

It is concluded that the first and second iteration results are the same, then $\mathrm{n}=115$ of private vocational training institutions is taken in 19 districts/cities in North Sumatera province. Based on proporsionate random sampling at 19 locations throughout the population, there are 719 private vocational training institution used as the sample.

Analysis and Hypothesis Testing: The analysis is conducted to test the hypothesis in this study by using path analysis. The hypothesis testing is done by the magnitude of the estimated and calculated path coefficients based on the observed data. 


\section{Findings}

The Correlation of Situational Leadership Behavior and Organizational Culture On Private Vocational Training Institutes: The first hypothesis is a correlation between situational leadership behavior with organizational culture on private vocational training institutes. The statistical hypothesis test as follows:

$\mathrm{H}_{1}: \mathrm{Px}_{2} \mathrm{x}_{1} \neq 0$, there is a correlation between situational leadership behavior with organizational culture in private vocational training institutes.

It is found a strong correlation between the value of situational leadership behavior with organizational culture in private vocational training institutes by 0.60 , means the changes of situational leadership behavior have an impact on organizational culture by 60 percent or visa versa. The hypothesis states that the value of $t=2.14$ is greater than $t_{\text {table }}$ of 1.98 . This means there is a significant correlation between situational leadership behavior to organizational culture in private vocational training institutions in the province of North Sumatra. The results are consistent with the findings by Mello (2002, p.107) that mentioned leadership behaviors and organizational culture which occur as internal to a company is an important factor in increasing the strength of the productivity and profitability of the company. Furthermore Kreitner \& Kinichi $(2003$, p.86) states of organizational culture in the operation led by the situational leadership behavior can improve the productivity of the company.

The Effect of Situational Leadership Behavior and Organizational Culture on the Implementation of Human Resource Management Strategy: The second hypothesis, there is an effect of situational leadership behavior and organizational culture on the implementation of human resource management strategies in private vocational training institutes. The test is done with path analysis. Below is the hypotheses test simultaneously:

$\mathrm{H}_{1}$ : $\mathrm{px}_{3} \mathrm{x}_{1} \neq 0$, means that situational leadership behavior and organizational culture significantly influence the implementation of human resource management strategies in private vocational training institutions in North Sumatera province.

The criteria is to reject $\mathrm{H}_{0}$ if the value of $\mathrm{F}>\mathrm{F}_{\alpha}(p-1 ; n-p)$. For the regression equations that being tested $\mathrm{p}=$ 2 and $n=115$, where $p$ is the number of parameters and $n$ is the number of observations, with 95 percent of confidence level. The results found the value of $F=13.14$ is much greater than the value of $F_{\text {table }}=3.08$, then the test is significant and $\mathrm{H}_{0}$ is rejected. There is the influence of situational leadership behavior and organizational culture on the implementation of human resource management strategies in private vocational training institutes by 0.19 or 19 percent while the influence of other variables is by 81 percent. Partial test results of situational leadership behavior and organizational culture has a significant influence on the implementation of human resource management strategies in private vocational training institutions in North Sumatera province which performed by t test shown in Table below.

Table 2: Statistical Test

\begin{tabular}{llllll}
\hline Structural Parameter & Path Coefficient & $\mathbf{T}$ & $\mathbf{T}_{\text {tabel }}$ & Decision & Effect \\
\hline $\mathrm{Px}_{3} \mathrm{X}_{1}$ & 0.23 & 2.14 & 1.98 & Reject $\mathrm{H}_{0}$ & Significant \\
$\mathrm{Px}_{3} \mathrm{X}_{2}$ & 0.25 & 2.37 & 1.98 & Reject $\mathrm{H}_{0}$ & Significant \\
\hline
\end{tabular}

Where:

$\mathrm{X}_{1}=$ Situational Leadership Behavior

$\mathrm{X}_{2}=$ Organizational Culture

$\mathrm{X}_{3}=$ Implementation of Human Resource Management Strategy

The 5 percent significance level $(\alpha)$ test found the effect of leadership behavior partially on the implementation of human resource management strategies by 23 percent, while the influence of organizational culture by 25 percent. Based on the test results, situational leadership behavior and organizational culture have a significant effect, either simultaneously or partially to the implementation of human resource management strategies in private vocational training institutions in North Sumatera province. The implementation of human resource management strategy is supported by the situational 
leadership behavior and organizational culture, thus the increase productivity of private vocational training institutions in North Sumatera province will be achieved. The situational leadership behavior is the accuracy of the leadership behavior's combination of task behavior, behavior and maturity subordinate relationship. This is in accordance with the findings by Blanchard \& Hersey (1993, p.84), Kreitner \& Kinichi (2002, p.566), and Goodwin \& Wofford (2001, p.759). Its suggest that the behavior as a manifestation of situational leadership affect the ability of a group of people to achieve the goals of the organization in accordance with the demands of the subordinate situation.

The leaders of private vocational training institutions are required to be able to influence, change and direct the actions of subordinates through cooperation and communication in order for them to work productively. Situational leadership behavior in private employment training institutions displayed by leaders with a combination of behaviors that are associated with tasks and human resources as well as subordinate maturity level (Blanchard \& Hersey, 1993, p.192). Meanwhile, the culture determines the coaching and non-coaching labor organizations at private vocational training institutions in North Sumatera province in doing work with collaboration and normative belief. The organizational culture is a manifestation held assumption, accepted by all workers in the organization and determine how they feel, think and work together to improve the productivity and profitability of private vocational training institutions. The results are consistent with the opinion by Kreitner \& Kinichi $(2003$, p.89), that there are four general manifestation of organizational culture that held in common, spoken words concurrently, work together and felt carried along in for an organization to improve the productivity of the company.

The implementation of human resource management strategy refers to an integrated master plan, coordinated and linking managerial and operational functions of human resource management that includes dimensions of proper recruitment and selection, training programs in accordance with the results of the training needs analysis, performance assessment with the right system, system viable and fair compensation and labor relations in an effort to increase productivity of private employment training institutions in North Sumatera province. The results are consistent with the opinion by Mello (2002, p.237) and Fulmer (2001, p.3) stated that the implementation of human resource management strategy that includes dimensions of recruitment, selection, training, compensation and labor relations are supported the situational leadership behavior and organizational culture which can improve total productivity of a company.

The Effect of Implementation Strategy Human Resource Management on Productivity of Private Employment Training Institute: The third hypothesis is there is significant implementation of human resource management strategies on the productivity of private vocational training institutions in North Sumatera province. The proposed hypothesis is as follows:

$\mathrm{H}_{1}: \mathrm{Pyx}_{3} \# 0$, means that there is an effect of the implementation strategy of human resource management on the productivity of private vocational training institutions in North Sumatera province.

The results found that the implementation of human resource management strategy has a direct influence on the productivity of the training institute by 11.56 percent, while the remaining 88.44 percent is influenced by other variables. There are other variables that can improve the productivity of private vocational training institutions such as physical support, reputation and size of the vocational training institutions. The path coefficients of $X_{3}$ is 0.34 means each increase of standard deviation in the value of an average in implementation of human resource management strategy will increase the productivity of training institutions by 34 percent. An indirect effect through situational leadership behavior by 6.72 percent and the organizational culture by 3.45 percent. In total of direct and indirect effect on the implementation of human resource management strategy for productivity of training institutes is 21.73 percent. The test results influence the $\mathrm{Pyx}_{3}$ path coefficient, shows the implementation of human resource management strategy has a significant effect on the productivity of vocational training institutions because $t=6.33$ is greater than $t_{\text {table }}=1.98$. The results in accordance with the opinion by Mello (2002, p.237), Noe et al. (2000, p.53), Carrell et al. (1995, p.9), Dessler (2000, p.21), Becker et al. (2001, p.37) and Falbe (1996, p.140), that the implementation of human resource management strategy with operational functions of recruitment, selection, training, performance appraisal, compensation and labor relations is contribute to the increased productivity of labor training institutions because of human resources able to master the technology to make the quality of goods and services. 
Influence of Situational Leadership Behavior, Culture and Implementation Strategy Organization of Human Resource Management on Productivity Private Employment Training Institute: The fourth hypothesis is the situational leadership behavior, organizational culture and the implementation of human resource management strategy affect the productivity of private vocational training institutes. The hypothesis test is done using a statistical test of path analysis of each variable. The proposed of simultenous hypotheses are as follows:

$\mathrm{H}_{1}$ : $\mathrm{Pyx}_{3} \neq 0$, means that situational leadership behavior, organizational culture and implementation of human resource management strategies simultaneously influence on the productivity of training institutions.

Based on the results of determinant coefficient that situational leadership behavior, organizational culture and implementation of human resource management strategies simultaneously have a significant effect on the productivity of training institutions by 83 percent and the influence of other variables is by 17 percent. Simultaneouly the test is significant with $F$ value $=180.65$, it is greater than the $F_{\text {table }}=2.69$, thus to reject the $\mathrm{H}_{0}$. Partially, the influence of situational leadership behavior, organizational culture and the implementation of human resource management strategies on the productivity of labor training institute are seen from the path coefficients of each variable, namely; i) situational leadership behaviors' path coefficient is 0.52 , indicated that every increase of one standard deviation of situational leadership behavior will increase the value of the institution productivity by 52 percent; ii) organizational culture path coefficient is 0.26 , indicate that every increase of one standard deviation of organizational culture will increase the value of 26 percent of productivity training institutions; iii) the human resource management strategy has the path coefficient of 0.34 , this indicates that every increase of one standard deviation or the implementation of human resource management strategy will increase in productivity of private vocational training institutions by 34 percent.

The results of statistical tests of partial influence of situational leadership behavior, organizational culture and the implementation of human resource management strategies on the productivity of private vocational training institutions in North Sumatera province shown in Table below:

Table 3: Statistics Test Results

\begin{tabular}{llllll}
\hline Structural Parameter & Path Coefficient & $\mathbf{T}$ & $\mathbf{T}_{\text {tabel }}$ & Decision & Effect \\
\hline $\mathrm{Px}_{3} \mathrm{x}_{1}$ & 0.52 & 10.45 & 1.98 & Reject $\mathrm{H}_{0}$ & Significant \\
$\mathrm{Px}_{3} \mathrm{x}_{2}$ & 0.26 & 5.26 & 1.98 & Reject $\mathrm{H}_{0}$ & Significant \\
$\mathrm{Pyx}_{3}$ & 0.34 & 7.78 & 1.98 & Reject $\mathrm{H}_{0}$ & Significant \\
\hline
\end{tabular}

Where:

$\mathrm{X}_{1}=$ Situational Leadership Behavior

$\mathrm{X}_{2}=$ Organizational Culture

$\mathrm{X}_{3}=$ Implementation of Human Resource Management Strategy

$\mathrm{Y}=$ Productivity Private Employment Training Institute, 2004.

Partially, the situational leadership behavior has a significant effect on the productivity of private vocational training institutions because $t$ is 10.45 greater than $t_{\text {table }}=1.98$. Then, partially the organizational culture significantly influence the productivity of private vocational training institutions because $t=5.26$ is greater than $t_{\text {table }}=1.98$. Lastly, partially the implementation of human resource management strategy has a significant effect on the productivity of private vocational training institutions because $t=7.78$ is greater than $t_{\text {table }}=1.98$. The direct and indirect influence of situational leadership behavior, organizational culture and the implementation of human resource management strategies on the productivity of private vocational training institutions, namely (i) the magnitude of the direct influence of situational leadership behavior determines the productivity of labor training institutions by 27.04 percent and 8.11 percent through the culture of the organization, through the implementation of human resource management strategy by 6.72 percent. The total effect of leadership behaviors determine the productivity training institutes is 41.87 percent; (ii) the magnitude of the direct influence of organizational culture determines the productivity of training institutions by 6.86 percent, through situational leadership behaviors is 8.11 percent and through the implementation of human resource management strategy is 3.45 percent. The total effect of organizational culture determines the productivity of training institute is 19.32 percent; (iii) the magnitude of the direct effect of the implementation of human resource management strategies to changes in the productivity of labor 
training institute is 11.56 percent, through situational leadership behaviors by 6.72 percent and 3.45 percent through the organizational culture. The total effect of the implementation of human resource management strategy determines changes in the productivity of labor training institute at 21.73 percent. It is found that situational leadership behaviors contribute the largest direct influence by 27.04 percent of the productivity of labor training institutions.

Based on the above results, it can be concluded that the growth of labor force still require job training in private vocational training institutions, which is a good prospect for private vocational training institutions. This prospect requires leaders of training institutions to improve productivity in operations and delivery of training services that require a level of situational leadership behavior according to the situation of the subordinate maturity in accordance with the opinion of Melo (2002), the implementation of human resource management strategy contributes to corporate strategy. The situational leadership behavior correlated strongly to the organizational culture. If there is a change in the level of ability of situational leadership behavior, it will have an impact on the implementation of organizational culture change. These two variables are interrelated as well as the donation that has a significant impact on the implementation of human resource management strategies and productivity of private vocational training institutions in North Sumatera province. The results are consistent with the opinion by Noe et al. (2000, p.53) and Marks et al. (1998, p.61) states that the implementation of corporate strategies require human resources who have the knowledge, skills and attitudes which have contribution as the determinant of work towards improved performance, productivity and profitability of the company.

The situational leadership behavior and organizational culture have an internal relation to the company used as the important factors in increasing the productivity. Both are either simultaneously or partially have a significant effect on the implementation of human resource management strategy which encourage workers in having responsibilities, normative beliefs and motivation to work and possess the competence to improve the productivity of private vocational training institutions in North Sumatera province. The results are consistent with the opinion by Mello (2002) that stated the implementation of human resource management strategies can effectively improve the performance and productivity, labor satisfaction and customer satisfaction, and increase the value of securities to shareholders. The situational leadership behavior, organizational culture and the implementation of human resource management strategies simultaneously have a significant effect for 83 percent to the increase in the productivity of private vocational training institutions in North Sumatera province. Partially, the situational leadership behavior determines the productivity of private vocational training institutions by 52 percent compare to 26 percent of the application of the organizational culture and 34 percent of the implementation of human resource management strategies.

The direct effect on the productivity of situational leadership behavior vocational training institutions is by 27.04 percent more than the organizational culture and the implementation of human resource management strategy. The indirect effect of situational leadership behavior through organizational culture is similar as the indirect effect of organizational culture through situational leadership behavior on the productivity of private vocational training institutions which is 8.11 percent. The situational leadership behavior and organizational culture are the two variables that interrelated and supported the improvement of the productivity of private vocational training institutions in North Sumatera province. In general, the behavior of situational leadership, organizational culture and the implementation of human resource management strategies in private vocational training institutions in North Sumatera province rated somewhat higher. The human resources sufficiently competent and driven by situational leadership behavior and implement constructive organizational culture can improve the productivity of private vocational training institutions in North Sumatera province. The level of productivity of private vocational training institutions in North Sumatera province is generally considered sufficient whereby in 2012 there is an increase of 3.93 percent from the year 2011, unless the contribution to the public training institutions, namely the establishment of a special job fairs, information systems training and scholarships are assessed still below par. The results showed that the physical environment support of private vocational training institutions are generally sufficient.

The observations and interviews show that the relationship of cooperation of the training institutions with the industry for the development of training and apprenticeship programs and assist the placement of graduates generally is low. The training program conducted by private vocational training institutions in North Sumatera province has not been developed according to the needs of the industry, so that the qualifications of graduates and the placement of graduates are low respectively. The findings of this study 
is rational because the service industry in the operation and delivery of vocational training services requires a high level of situational leadership behavior and constructive of application of organizational culture and effectiveness of the implementation of human resource management strategy, in which can improve the productivity of private vocational training institutions in North Sumatera province. Further research can be developed by comparing the vocational training institutions belong to the community with job training agencies of government as well as the additional of other variables on productivity, quality and profitability of private vocational training institutions in North Sumatera province.

\section{Conclusion and Recommendations}

Based on the results of research, it can be concluded as follows:

- The situational leadership behavior and organizational culture in private vocational training institutions in North Sumatera province generally considered high. The largest value is obtained by the situational leadership behavior of delegation dimension, while the greatest value of the organizational culture is a constructive organizational culture. The implementation of human resource management strategy that includes recruitment, selection, training, performance appraisal, compensation and labor relations are generally considered sufficient. The productivity of private vocational training institutes is considered sufficient unless the contribution of vocational training to public institutions such as the presence of specific labor market and scholarships rated to be low. The cooperation of private vocational training institutions with industry in order to graduate placement, apprenticeship programs and the development of training programs considered low.

- The situational leadership behavior significantly correlated with organizational culture through the dimensions of telling, selling, participating and delegating. The organizational culture is interrelated and support the implementation of human resource management strategy in increasing the labor productivity of private institutions in North Sumatera province.

- The situational leadership behavior and organizational culture have a significant effect simultaneously and partially on the implementation of human resource management strategies in private vocational training institutions in North Sumatera province. The situational leadership behavior is able to affect more than the organizational culture in the implementation of human resource management strategy. The organizational culture motivates a group of workers in the completion of tasks with achieving objectives through cooperation, normative, innovative, creative and support the implementation of human resource management strategy which increase the productivity of private vocational training institutes.

- The implementation of human resource management strategies has a significant effect on productivity improvement of private vocational training institutions in North Sumatera province. The competent human resources are able to apply technology in increasing productivity to produce quality graduates.

- The situational leadership behavior, organizational culture and the implementation of human resource management strategy that includes recruitment, selection, training, performance appraisal, compensation and labor relations have a significant effect simultaneously and partially to the increased productivity of private vocational training institutions in North Sumatera province.

- The private training institutions in North Sumatra province does not have a program to deal with complaints against service training. Handling the trainees' complaints is required to increase training services.

Recommendation: Based on the research results and conclusions, there are proposed recommendations as follows:

- The institute of job training need to pay more attention to the situational leadership behavior by achieving a combination of task behavior, behavior and maturity subordinate relationship through; (i) telling dimension by setting clear tasks and responsibilities, designing productive ways of working, giving detailed instructions, emphasizing cooperation to control the situation of subordinate maturity level; (ii) selling dimensions, to include suggestions of subordinates in decision making and goal setting of vocational training institutions, providing ease of consultation and provide guidance as well as controlling the effective work in situations of low to medium maturity subordinates; (iii) participating dimensions include suggestions subordinates in decision making and goal setting, always communicating with subordinates, cooperation, motivate and provide guidance and effective controls on the maturity level is moderate to high; 
(iv) delegating dimensions to give sufficient guidance and counseling as well as delegate authority and responsibility to the subordinates.

- The institute of private job training needs to pay more attention to the level of implementation of constructive organizational culture because it will affect the implementation of human resource management strategy and increase the productivity of private vocational training institutions.

- In order to increase productivity, the private vocational training institutions should pay more attention to the implementation of human resource management strategy that include; recruitment in accordance with manpower planning, selection according to job requirements, manpower training in accordance with the results training assessment needs, objective performance appraisal, adequate and equitable compensation system, create a harmonious labor relations, comply with applicable laws and regulations and the establishment of a formal association of trade unions.

- The institute of private job training needs to further improve the training services to the community by providing appropriate training materials in accordance with the results of the analysis of training needs, provides professional instructors and enhances the works' contributions to the public training institutions such as the presence of specific labor market and increase scholarships cooperation between vocational training institutions and industry.

- To increase the contribution to society, the private job-training institute shapes the labor market in the effort to find graduates, develops the training information systems and provides scholarships to potential students.

- The institutions of private job training need to pay more attention to the maintenance and renovation of the physical environment such as building facilities, training structures and equipment, rooms, bathrooms, parking, environmental cleanliness and parking arrangements.

- The author suggests, further research is expected to find other factors beyond the variables of situational leadership behavior, organizational culture and the implementation of human resource management strategies that affect the productivity, quality and profitability of private vocational training institutions in order to enrich the knowledge economy, particularly human resource management and organizational behavior.

\section{Reference}

Becker, B. E., Mark A. H. \& Dave U. (2001). HR Scorecard Lingking People, Strategy and Performance, Harvard Business School Press. Boston, Massachusetts.

Blanchard, K. \& Hersey, P. (1993). Management of Organizational Behavior: Utilizing Human Resources, $6^{\text {th }}$ edition, Prentice Hall Inc., Engelwood Clifts, New Jersey.

Carrell, M. R., Norbert, F. E. \& Robert, D. H. (1995). Human Resource Management, Global Strategies for Managing a Diverse Work Force, Fifth Edition, Prentice Hall, Englewood.

Cushway, B. (2002). Human Resources Management, AMED (The Association for Management Education and Development), Cetakan ketiga, Penerbit P.T. Elex Media Komputindo Gramedia, Jakarta.

Dessler, G. (2000). Human Resources Management, Eight Edition, Prentice Hall International Inc., California.

Djalaludin, R. (2000). Metode Penelitian untuk Bisnis, Edisi Kelima, Media Pustaka Jakarta:

Falbe, C. M. (1996). The Role of Maintenance Functions Human Resource Management in Improving The Quality of Working Life at The Service Industry. Journal of Psychology, 140(2).

Fulmer, R. M. (2001). Johnson \& Johnson: Frameworks for Leadership. Journal of Organizational Dynamics, 29(3).

Gibson, J. L., John, M., Ivancevich, J. H. \& Donnely, Jr. (1997). Organisasi, Edisi Ke Delapan, Binarupa Aksara, Jakarta.

Goodwin, V. L. \& Wofford, J. C. (2001). A Laboratory Goodwin, Vicki L., and J.C. Wofford, 2001, A Laboratory Experiment Testing the Antecedent of Leader Cognitions. Journal of Organizational Behavior, 22, 759-774, University of Nort Texas, Denton, Texsas, U.S.A.

Kreitner, K. \& Kinichi, A. (2003). Organization Theory and The New Public Administration, Boston : Allyn and Bacon Inc.

Kreitner, K. \& Kinicki, A. (2002). Organizational Behavior, New York: Mc. Graw-Hill Companies.

Kreitner, K. \& Kinicki, A. (2000). Organizational Behavior, Diterjemahkan oleh Erly Suandy, Penerbit Salemba Empat, Jakarta.

Lovelock, C. (2002). Service Marketing and Management, USA: Prentice Hall International Inc., 50-71 
Marks, M. L., Mirvis, P. H., Hacket, F. J. \& Grady, J. F. (1998). Employee Participation in a Quality Circle Program: Impact on Quality of Work Life Productivity, and Absenteeism. Journal of Applied Psychology, 61(89).

Mello, J. (2002). Strategic Human Resources Management, Printed in the United States of America, SouthWestern College Publishing, Ohio.

Noe, R. A., John, R. H., Berry, G. \& Patrick, M. W. (2000). Human Resource Management, Gaining a Competitive Advantage, Third Edition, Prentice Hall, Mc. Inc, U.S.A.

Robbins, S. P. (1998). Organizational Behavior: Concepts, Controversies, Applications, Eighth Edition, New York.

Robbins, S. P. (2003). Organizational Behavior: Contemporary Issues in Leadership, New Jersey: Prentice Hall.

Schroeder, R. G. (2000). Operations Management, Contemporary Concepts and Cases, International Edition, McGraw-Hill Higher Education, University of Minnesota, Boston.

Sekaran, U. (2000). Research Methods for Business, Third Edition, Printed in the United States of America.

Tiwana, A. (2001). The Essential Guide to Knowledge Management, E- Business and CRM Application, Prentice Hall Inc., U.S.A.

Zeithaml, V. A. \& Mary, J. B. (2000). Service Marketing, Singapore: Mc Graw-Hill Companies Inc. 